\title{
MASALAH KESEHATAN PENYINTAS GEMPA DAN TSUNAMI \\ DI DONGGALA, SIGI DAN PALU, SULAWESI TENGAH
}

\author{
Health Problems Of Survivor Earthquake And Tsunami In \\ Donggala, Sigi And Palu, Central Sulawesi
}

\author{
Bambang Wiseno ${ }^{1}$ \\ ${ }^{1}$ Dosen Akademi Keperawatan Pamenang - Kediri
}

\begin{abstract}
ABSTRAK
Indonesia sebagai negara kepulauan yang berada di garis patahan bumi ( Ring of Fire) telah banyak terjadi bencana alam. Pada tanggal 28 September 2018 gempa dengan kekuatan 7,7 SR terjadi yang menimbulkan tsunami di Donggala, Sigi dan Palu Provinsi Sulawesi Tengah. Dinyatakan sebagai bencana nasional maka pemerintah dan juga banyak organisasi kemanusiaan / Non Goverment Organisation (NGO) baik dalam negeri maupun luar negeri yang membantu menangani permasalahan yang diakibatkannya. Untuk masalah ini, penulis sebagai dosen dan salah satu anggota NGO Persatuan Bulan Sabit Merah Indonesia (BSMI) setelah dua minggu bencana, melakukan pelayanan kesehatan dan pemberian bantuan untuk meringankan beban bio, psiko, sosio dan kultural. Sebanyak 845 warga memeriksakan kesehatan di pos-pos kesehatan yang dibuat. Permasalahan kesehatan yang ditemukan adalah diare dan gangguan pencernakan, infeksi saluran pernafasan, hipertensi, penyakit kulit serta berbagai permasalahan post trauma syndroma disorder. Berdasarkan literatur dan temuan tersebut dapat disimpulkan, bahwa masalah-masalah tersebut perlu mendapatkan perhatian lebih dalam penanganan dan pencegahannya serta penolong / relawan harus mempunyai kesiapan memberikan dukungan kesehatan jiwa / psikososial paska bencana.
\end{abstract}

Kata Kunci: Gempa, Tsunami, Donggala, Palu, Sigi, Post Traumatic Syndroma Disorder, Psikososial, Bencana.

\begin{abstract}
Indonesia is an archipelago country located on the Ring of Fire has experienced many natural disasters. On September 28, 2018 a earthquake with magnitude 7.7 caused a tsunami in Donggala, Sigi and Palu in Province of Sulawesi Tengah. Declared a national disaster, the government and many humanitarian organizations (NGOs) domestic and foreign, who are help to deal the problems caused. For this matter, writers is a llecturer and one's of memberf the NGO Indonesian Red Crescent Society (BSMI) after two weeks of disaster have conduct health services and provide assistance to alleviate the bio, psychological, socio and cultural burden. Nearly 845 residents checked their health conditions at health posts created. Health problems found were diarrhea and digestive disorders, respiratory tract infections, hypertension, skin diseases and various post-traumatic syndroma disorder problems. Based on the literature and these findings it can be concluded, the problems needs more attention in the handling and prevention, and helper / voluntere should be readiness to provide mental health / psychosocial support after the disaster.
\end{abstract}

Key word: Earthquake, Tsunami, Donggala, Palu, Sigi, Post Traumatic Syndromes Disorder, Psychosocial, Disaster. 


\section{A. Analisis Situasi}

Negara Indonesia sebagai negara kepulauan yang terletak dalam "ring of fire" lempeng dunia mengakibatkan sering terjadinya bencana khususnya gempa bumi dan gunung meletus. Gempa tengan kekuatan 7,4 Skala Richter (SR) melanda wilayah Lombok dan sekitarnya yang menngakibatkan banyak rumah rusak, ratusan orang dinyatakan meninggal dunia. Disusul pada tanggal 28 September 2018 gempa dengan kekuatan 7,7 SR terjadi kembali yang menimbulkan tsunami di Donggala, Sigi dan Palu Provinsi Sulawesi Tengah. Ribuan manusia meninggal dunia dan ribuan orang sampai kegiatan ini dilakukan dinyatakan hilang. Selain korban harta benda yang tak terhitung dan rusaknya infrastruktur termasuk tempat pelayanan kesehatan, juga menyisakan permasalahan kesehatan yang sangat berat. Trauma paska bencana mengakibatkan permasalahan yang lebih luas lagi bila tidak mendapat penanganan kesehatan secara cepat dan tepat.

Memperhatikan permasalahan kesehatan paska bencana yang mana bencana tersebut dinyatakan sebagai bencana nasional maka selain pemerintah juga banyak organisasi kemanusiaan / Non Goverment Organisation (NGO) baik dalam negeri maupun luar negeri yang berusaha membantu menangani permasalahan tersebut. Salah satu yang bisa dilaksanakan adalah dengan melakukan pelayanan kesehatan dan pemberian bantuan untuk meringankan beban bio, psiko, sosio dan kultural.

Sesuai tanggungjawab dalam pendidikan tinggi dengan tridharma yang berupa pembelajaran, pengabdian masyarakat dan penelitian, memberikan pelayanan kesehatan dalam bencana sangatlah diperlukan. Perlunya pelayanan kesehatan paska bencana yaitu untuk mencegah terjadinya penyakit yang lebih berat, meningkatkan derajat kesehatan dan membantu masyarakat untuk mendapatkan kehidupan normal secepatnya.

\section{B. Perumusan Masalah}

Berdasarkan latar belakang diatas dan diskusi dengan bagian pengabdian masyarakat serta NGO yang ada, maka permasalahan yang ada yaitu kurangnya pelayanan kesehatan dan kurangnya kebutuhan pokok di lokasi gempa dan tsunami. Untuk hal tersebut, maka dilakukan pengiriman tenaga kesehatan (dosen) untuk memberikan pelayanan kesehatan sebagai bentuk pengabdian masyarakat dalam tridharma perguruan tinggi.

\section{Realisasi Penyelesaian Masalah}

Pelayanan kesehatan dengan pemeriksaan kesehatan terhadap masyarakat dan konseling kejiwaan / pendampingan kejiwaan untuk meningkatkan koping korban terhadap masalah yang dihadapi. Pemberian bantuan bahan makan dengan membagikan kebutuhan pokok pada masyarakat korban gempa dan tsunami yang berhasil dikumpulkan oleh NGO rekanan khususnya pada kelompok yang belum mendapatkan pelayanan dalam hal ini.

\section{Khalayak Sasaran}

Khalayak sasaran pada kegiatan pelayanan kesehatan dan pemberian bantuan ini yaitu masyarakat korban / kelompok rentan bencana gempa dan tsunami di Donggala, Sigi dan Palu, Provinsi Sulawesi Tengah. Koordinasi dengan tim relawan lain dan tim relawan lokal dilakukan untuk menentukan lokasi yang belum mendapatkan pelayanan kesehatan di daerah terisolir dan jauh dari tempat pelayanan kesehatan yang rusak akibat bencana.

\section{E. Persiapan}

Persiapan yang dilakukan sebelum keberangkatan ke lokasi bencana meliputi:

1. Perijinan dan koordinasi dengan NGO Bulan Sabit Merah Indonesia (BSMI Jawa Timur) untuk memberikan pelayanan kesehatan dan pemberian bantuan;

2. Menyiapkan kebutuhan obat-obatan untuk paska bencana dan menyiapkan kebutuhan bahan pokok yang akan disalurkan kepada korban bencana;

3. Mengurus kelengkapan administrasi kegiatan pengabdian masyarakat termasuk surat tugas dari Ketua LPPM Akademi Keperawatan Pamenang - Kediri dan surat tugas permintaan bergabung sebagai tim relawan dari NGO (BSMI Jawa Timur);

4. Menyiapkan proposal kegiatan pengabdian masyarakat yang berisi Preplanning dengan NGO serta rencana penggunaan anggaran;

5. Menyiapkan kebutuhan keberangkatan termasuk akomodasi ke lokasi dengan berkoordinasi dengan NGO;

6. Menyiapkan kelengkapan kebutuhan pribadi menyiapkan peralatan komunikasi untuk dapat memudahkan koordinasi dengan tim relawan laiin yang ada di lokasi bencana;

\section{F. Metode yang Digunakan}

Kegiatan yang dilakukan yaitu dengan memberikan pelayanan kesehatan berupa pemeriksaan kesehatan dan pengkajian kesehatan khususnya masalah kejiwaan untuk bisa melakukan dukungan kesehatan jiwa / psikososial serta pembagian bantuan bahan pokok. 
Bersama dengan tim medis dari BSMI memberikan obat-obatan standar bencana bagi yang terdeteksi mengalami penyakit paska bencana. Pemetaan kebutuhan dan keadaan dilakukan untuk memudahhkan kelanjutan penanganan masalah yang ditimbulkan paska bencana.

\section{G. Kegiatan}

Pelaksanaan pelayanan kesehatan, dukungan kesehatan jiwa / psikososial dan pembagian bahan pokok dilakukan mulai tanggal 15 - 29 Oktober 2018 di berbagai lokasi antara lain:

1. Layanan Kesehatan berupan pemeriksaan kesehatan dan pengobatan dasar diberikan bekerja sama dengan NGO Yayasan Dana Sosial Al-Falah (YDSF) dan Bulan Sabit Merah Indonesia (BSMI) pada:

\begin{tabular}{|c|c|c|}
\hline Hari/Tanggal & Tempat & Jumlah \\
\hline $\begin{array}{l}\text { Selasa / } \\
16-10-2018\end{array}$ & $\begin{array}{l}\text { Ds. Lelea, Kec. } \\
\text { Labuan, Kabupaten } \\
\text { Donggala }\end{array}$ & $\begin{array}{l}56 \text { warga } \\
(4 \quad \text { home } \\
\text { visite, } 2 \\
\text { rawat luka) }\end{array}$ \\
\hline $\begin{array}{l}\text { Selasa / } \\
16-10-2018\end{array}$ & $\begin{array}{l}\text { Dsn. Taripapanda, } \\
\text { Ds. Labuan, Kec. } \\
\text { Labuan, } \\
\text { Donggala }\end{array}$ & 59 warga \\
\hline $\begin{array}{l}\text { Rabu / } \\
17-10-2018\end{array}$ & $\begin{array}{ll}\text { Ds. Lende, } & \text { Kec. } \\
\text { Sirinja, } & \text { Kab. } \\
\text { Donggala } & \end{array}$ & 30 warga \\
\hline $\begin{array}{l}\text { Rabu / } \\
17-10-2018\end{array}$ & $\begin{array}{l}\text { Ds. Lende } \\
\text { Kec. Sirinja, Kab. } \\
\text { Donggala }\end{array}$ & $\begin{array}{l}50 \text { warga } \\
\left(\begin{array}{c}1 \\
\text { visite })\end{array}\right.\end{array}$ \\
\hline $\begin{array}{l}\text { Kamis / } \\
18-10-2018\end{array}$ & $\begin{array}{l}\text { Ds Batusuya, Kec. } \\
\text { Sindue Tobata, Kab. } \\
\text { Donggala }\end{array}$ & $\begin{array}{l}140 \text { warga } \\
(11 \text { home } \\
\text { visite })\end{array}$ \\
\hline $\begin{array}{l}\text { Jumat / } \\
19-10-2018\end{array}$ & $\begin{array}{l}\text { Dsn. Silaru, Desa } \\
\text { Sindosa, Kec. } \\
\text { SindueTombusabora, } \\
\text { Kab. Donggala }\end{array}$ & $\begin{array}{l}51 \text { warga } \\
\text { ( } 4 \text { home } \\
\text { visite) }\end{array}$ \\
\hline $\begin{array}{l}\text { Sabtu / } \\
20-10-2018\end{array}$ & $\begin{array}{l}\text { Desa Kaliburu, } \\
\text { Kecamatan Sindue } \\
\text { Tobata, Kabupaten } \\
\text { Donggala. }\end{array}$ & $\begin{array}{l}120 \text { warga } \\
(5 \text { home } \\
\text { visite })\end{array}$ \\
\hline $\begin{array}{l}\text { Minggu / } \\
21-10-2018\end{array}$ & $\begin{array}{ll}\text { Ds Tambu, } & \text { Kec. } \\
\text { Balaesang, } & \text { Kab. } \\
\text { Donggala } & \end{array}$ & $\begin{array}{l}80 \text { warga } \\
(5 \text { home } \\
\text { visite })\end{array}$ \\
\hline $\begin{array}{l}\text { Kamis / } \\
25-10-2018\end{array}$ & $\begin{array}{ll}\text { Dsn Baku, } & \text { Desa } \\
\text { Batusuya, } & \text { Kec. } \\
\text { Sindue } & \\
\text { Tombusabora, } & \text { Kab. } \\
\text { Donggala } & \end{array}$ & $\begin{array}{l}40 \text { warga } \\
(1 \quad \text { home } \\
\text { visite })\end{array}$ \\
\hline
\end{tabular}

\begin{tabular}{|l|l|l|}
\hline Jumat / $26-10-2018$ & $\begin{array}{l}\text { Ds Sipeso, Kec. } \\
\text { Sindue } \\
\text { Tambosabora, Kab. } \\
\text { Donggala }\end{array}$ & \\
\hline $\begin{array}{l}\text { Sabtu / } 27-10-2018 \\
\text { Dsn 1 RT 7, Ds } \\
\text { Langaleso, Kec. } \\
\text { Biromaru, Kab. Sigi }\end{array}$ & \\
\hline $\begin{array}{l}\text { Minggu / } \\
28-10-2018\end{array}$ & $\begin{array}{l}\text { Ds Wani 1, Kab. } \\
\text { Donggala }\end{array}$ & 40 warga \\
\hline
\end{tabular}

2. Layanan Dukungan Kesehatan Jiwa / Psikososiial dilakukan bersama tim BSMI Jawa Timur pada;

\begin{tabular}{|c|c|c|}
\hline Hari/ Tanggal & Tempat & Jumlah \\
\hline $\begin{array}{l}\text { Jumat / } \\
26-10-2018\end{array}$ & $\begin{array}{l}\text { Ds Sipeso, Kec. } \\
\text { Sindue Tobata, Kab. } \\
\text { Donggala }\end{array}$ & $\begin{array}{l}40 \text { siswadi SD } \\
\text { dan SMP } \\
\text { Sindue Tobata }\end{array}$ \\
\hline $\begin{array}{l}\text { Jumat / } \\
26-10-2018\end{array}$ & $\begin{array}{l}\text { Balai desa } \\
\text { Batusuya, Kec. } \\
\text { Sinduetombusabora, } \\
\text { Kab. Donggala. }\end{array}$ & $\begin{array}{l}\text { Relawan lokal } \\
\text { dan tim } \\
\text { relawan dari } \\
\text { mahasiswa } \\
\text { Unair } \\
\text { sebanyak } \\
\text { kurang lebih } \\
35 \text { orang. }\end{array}$ \\
\hline $27-10-2018$ & $\begin{array}{l}\text { SMK Nusantara Jl } \\
\text { Pemuda Palu }\end{array}$ & 30 siswa \\
\hline
\end{tabular}

3. Pembagian Logistik dari dan bersama NGO BSMI Jawa Timur yang berupa bahan makan pokok, pakaian baru dan layak pakai, perlengkapan bayai dan anak termasuk susu dan makanan pendamping ASI, (Foto" terlampir) pada;

\begin{tabular}{|c|c|}
\hline Hari / Tanggal & Tempat \\
\hline $\begin{array}{l}\text { Selasa / } \\
16-10-2018\end{array}$ & $\begin{array}{l}\text { Desa Lelea, Kecamatan Labuan, } \\
\text { Kabupaten Donggala }\end{array}$ \\
\hline $\begin{array}{l}\text { Selasa / } \\
16-10-2018\end{array}$ & $\begin{array}{l}\text { Dusun Taripapanda, Desa Labuan, } \\
\text { Kecamatan Labuan, Kab. Donggala }\end{array}$ \\
\hline $\begin{array}{l}\text { Rabu / } \\
17-10-2018\end{array}$ & $\begin{array}{l}\text { Desa Lende, Kecamatan Sirinja, } \\
\text { Kabupaten Donggala }\end{array}$ \\
\hline $\begin{array}{l}\text { Rabu / } \\
17-10-2018\end{array}$ & $\begin{array}{l}\text { Desa Lende Induk, Kecamatan } \\
\text { Sirinja, Kabupaten Donggala }\end{array}$ \\
\hline $\begin{array}{l}\text { Kamis / } \\
18-10-2018\end{array}$ & $\begin{array}{l}\text { Desa Batusuya, Kecamatan Sindue } \\
\text { Tobata, Kabupaten Donggala }\end{array}$ \\
\hline $\begin{array}{l}\text { Jumat / } \\
19-10-2018\end{array}$ & $\begin{array}{l}\text { Dusun Silaru, Desa Sindosa, Kec. } \\
\text { Sindue Tombusabora Sirinja, Kab. } \\
\text { Donggala }\end{array}$ \\
\hline $\begin{array}{l}\text { Sabtu / } \\
20-10-2018\end{array}$ & $\begin{array}{l}\text { Desa Kaliburu, Kecamatan Sindue } \\
\text { Tobata, Kabupaten Donggala. }\end{array}$ \\
\hline $\begin{array}{l}\text { Minggu / } \\
21-10-2018\end{array}$ & $\begin{array}{l}\text { Desa Tambu, Kecamatan Balaesang, } \\
\text { Kabupaten Donggala }\end{array}$ \\
\hline $\begin{array}{l}\text { Kamis / } \\
25-10-2018\end{array}$ & $\begin{array}{l}\text { Dsn Baku, Desa Batusuya, Kec. } \\
\text { Sindue Tombusabora, Kabupaten } \\
\text { Donggala }\end{array}$ \\
\hline $\begin{array}{l}\text { Jumat / } \\
26-10-2018\end{array}$ & $\begin{array}{l}\text { Desa Sipeso, Kecamatan Sindue } \\
\text { Tambosabora, Kabupaten Donggala }\end{array}$ \\
\hline
\end{tabular}




\begin{tabular}{|l|l|}
\hline Sabtu / & Desa Langaleso, Dusun 1 RT 7, \\
$27-10-2018$ & Kecamatan Biromaru, Kabupaten Sigi \\
\hline $\begin{array}{l}\text { Minggu / } \\
28-10-2018\end{array}$ & Desa Wani 1, Kabupaten Donggala \\
\hline
\end{tabular}

4. Kegiatan Lain - lain

Pada tanggal 22, 23 dan 24 Oktober 2018 di Posko LOGISTIK, Rumah Sakit Lapangan BSMI) Jl. Pramuka Biromaru, Sigi, Sulteng melakukan pendataan penerimaan dan distribusian bantuan ke dan dari BSMI untuk korban di daerah bencana (foto terlampir).

\section{H. Evaluasi Hasil :}

1. Hampir 845 warga memeriksakan kesehatan dan mendapatkan pengobatan standar pasca bencana selama kegiatan dilakukan.

2. Dari hasil tabulasi pelayanan pemeriksaan kesehatan didapatkan penggolongan sebagai berikut

a. Berdasarkan umur:

- Balita: $171=20 \%$

- Anak-anak : $209=24,7 \%$

- Dewasa : $277=32,7 \%$

- Lansia : $191=22,5 \%$

b. Berdasarkan jenis kelamin:

- Laki-laki : $412=48,5 \%$

- Perempuan : $436=51,4 \%$

c. Berdasarkan jenis penyakit yang ditemukan:

- Diare dan gangguan Saluran

Pencernakan : $329=38,8 \%$

- ISPA : $179=21,1 \%$

- Hipertensi : $142=16,7 \%$

- Kulit : $87=10,3 \%$

- Lain-lain : $111=13,1 \%$

3. Ribuan paket bahan pokok dibagikan kepada masyarakat di lokasi bencana; (data pendukung terlampir)

\section{Pembahasan}

Diare dan gangguan Saluran Pencernakan terjadi pada $38,8 \%$ warga, merupakan permasalahan biasa terjadi pada bencana yang berhubungan dengan tersedia tidaknya pemenuhan kebutuhan air dan kebersihan. Seperti yang disampaikan oleh Paterson, Wright, dan Harris (2018), bahwa masalah kesehatan yang sering terjadi pada bencana banjir adalah gastroenteritis salah satunya. Kejadian diare, kesulitan air, kualitas air (air yang berbau, kotor dan adanya serangga dan cacing) (Sari dan Nofriya, 2018), akan menimbulkan banyak masalah kesehatan sehingga perlu meningkatkan ketahanan masyarakat untuk saling membantu dalam penyediaan air dan penyimpanan sumber air untuk menghindari kontaminasi. Perlunya pendidikan kesehatan khususnya tentang penyediaan air bersih untuk mencegah diare dengan persiapan masyarakat siap dalam menghadapi bencana. (Chan, Ho, Huang, Kim, Lam, Chung dan Chow, 2018).

Infeksi Saluran Pernafasan Atas menempati posisi kedua setelah diare yaitu sebesar $21,1 \%$. Dayan tahan tubuh manusia dalam keadaan bencana menurun drastis sehingga memudahkan tubuh terkena berbagai agent penyakit. Virus influensa akan mudah menular dalam keadaan personal hygiene yang jelek dan sanitasi yang buruk (Izumikawa, 2018).

Egawa, Murakami, dan Sasaki (2018) menjelaskan bahwa kebutuhan masyarakat akan obat-obatan anti hipertensi meningkat setelah bencana terbukti juga pada tsunami dan gempa di daerah ini. Dimana masalah hipertensi dengan besaran $16,7 \%$ pada pengungsi. Ketegangan fisik dan psikologis menjadikan warga pengungsi mengalami kekambuhan dan menyebabkan timbulnya kasus hipertensi baru.

Penyakit kulit adalah masalah kesehatan yang sering terjadi pada bencana banjir adalah penyakit kulit dan infeksi jaringan lunak karena perubahan atau rusaknya infrastruktur pelayanan kesehatan.: (Paterson, Wright, dan Harris, 2018). Pada bencana ini ditemukan sebesar 10,3\% kasus masalah kulit karena masih susahnya sarana dan prasarana untuk kebersihan. Hal ini tidak jauh berdeda dengan apa yang di sampaikan oleh Sameem, Aleem dan Manzoor, dan Dayrit, Bintanjoyo, Andersen, dan Davis, (2018), bahwa infeksi dan gatal-gatal kulit akan meningkat setelah terjadinya banjir.

Post Traumatic Syndroma Desease (PTSD) termasuk dalam permasalahan kesehatan jiwa yang menjadi perhatian (Shorter dan Kosten, 2018). Ketahanan dan kelentingan (resiliensi) warga dalam bencana akan mempengaruhi perilaku kesehatan untuk kehidupannya kedepan. Sehingga dukungan kesehatan jiwa / psikososial sangat perlu diberikan bagi warga untuk menghindari perilaku yang memperberat keadaan psikologisnya.

\section{J. Kesimpulan}

Penanganan gawat darurat bencana memerlukan koordinasi dan kerjasama dari semua elemen masyarakat dan organisasi, baik pemerintah maupun NGO untuk meringankan beban penderitaan warga korban gempa dan tsunami. Kerusakan infrastruktur pemerintahan dan khususnya untuk layanan kesehatan akan memungkinkan dan menyebabkan permasalahan kesehatan yang diakibatkan bencana. Pelayanan kesehatan harus mendapat perhatian khusus segera diberikan kepada korban dampak gempa dan 
tsunami yang berupa preventif dan kuratif. Permasalahan kesehatan yang muncul paska bencana (gempa dan tsunami) adalah akibat perilaku hidup bersih dan sehat tidak dapat dijalankan karena kerusakan infrastruktur yang ada. Personal hygiene yang tidak dapat dilakukan dengan baik menyebabkan berbagai penyakit seperti; penyakit saluran pencernakan, mendapatkan perhatian. Dukungan keserhatan jiwa dan psikososial dilakukan untuk anak-anak di sekolah, penampunan pengungsian dan di tempat layanan kesehatan (mobile clinic) diberikan untuk meningkatkan resiliensi terhadap bencana yang dialaminya.

\section{K. Saran}

1. Bagi Pemerintah

Recovery harus segera dilakukan untuk menghindari permasalah yang lebih banyak. Recovery hendaknya tidak hanya dilakukan untuk pengembalian dan pembangunan fisik namun dukungan keserhatan jiwa dan psikososial warga harus mendapatkan perhatian khusus. Pemerintah harus melibatkan NGO untuk mempercepat recovery sehingga korban mempunyai resilien yang baik dalammenghadapi bencana.

2. Bagi Non Goverment Organisation (NGO)

Terus meningkatkan peran serta nya dalam setiap permasalahan bencana yang terjadi di negara ini. NGO harus saling mampu berkoordinasi dan bekerja sama dengan pemerintah dalam menghadapi dan menyelesaikan permasalah akibat bencan.

3. Bagi Intitusi Pendidikan Kesehatan Mengikutsertakan civitas akademika dalam penanganan korban bencana dapat menambah ilmu dan pengetahuan bagi para tenaga pengajar dan mahasiswa. Keterlibatan intitusi pendidikan kesehatan dalam permasalahan yang terjadi pada kebencanaan akan meningkatkan kepekaan civitas akademika untuk dapat berperan di masyarakat yang sesuai dengan Tridharma Perguruan Tinggi khususnya dalam pengabdian masyarakat.

4. Bagi Relawan Bencana.

Kesiapan diri ketika terjun di wilayah bencana selain tekat juga kemampuan dalam menganalisa permasalahan yang ada di daerah bencana. Kemampuan dalam beroordinasi dengan instansi pemerintah termasuk tim relawan lain sangatlah diperlukan untuk bisa memberikan yang terbaik buat korban bencana. penyakit kulit dan penyakit saluran pernafasan selain masalah psikis yang tidak dapat dipungkiri menyebabkan semakin banyaknya warga yanga mengalami peningkatan tekanan darah.

Masalah psikososial yang dialami tidak hanya dialami oleh orang tua dewasa melainkan anak dan bayi yang merupakan kelompok rentan juga perlu

BSMI (2007). Anggaran Dasar dan Anggaran Rumah Tangga Perhimpunan Bulan Sabit Merah Indonesia. Web:http://bsmi.oc.id

Campbell, John E., (2012), International trauma life support for emergency care providers / edited by John Emory Campbell._-7th ed. Pearson Education Inc, New Jersey 07458 ISBN-13: 978-0-13-2157247, ISBN-10: 0-13-215724-1

Chan, E. Y. Y., Ho, J. Y. E., Huang, Z., Kim, J. H., Lam, H. C. Y., Chung, P. P. W., ... dan Chow, S. (2018). Long-Term and Immediate Impacts of Health Emergency and Disaster Risk Management (HealthEDRM) Education Interventions in a Rural Chinese Earthquake-Prone Transitional Village. International Journal of Disaster Risk Science, 9(3), 319-330.

Cuttrona, .E. (2014). Behavioral manifestation of social support: A microanalitic investigation. Journal of American Psychology Association. 0022-3514-865S00-75

Dayrit, J. F., Bintanjoyo, L., Andersen, L. K., dan Davis, M. D. P. (2018). Impact of climate change on dermatological conditions related to flooding: update from the International Society of Dermatology Climate Change Committee. International journal of dermatology.

Egawa, S., Murakami, A., dan Sasaki, H. (2018). Healthy Community Resilient Against Disaster. In The 2011 Japan Earthquake and Tsunami: Reconstruction and Restoration (pp. 139-152). Springer, Cham.

https://news.detik.com/berita/4233436/gempa-77-srguncang-sulteng-picu-peringatan-potensi-tsunami, diakses tanggal 30 Oktober 2018 pukul; 20:20 WIB

Izumikawa, K. (2018). Infection control after and during natural disaster. Acute Medicine dan Surgery.

Keliat, B.A, dkk (2011). Keperawatan Kesehatan Jiwa Komunitas: CMHN (Basic Course) Jakarta: EGC. Kemenkes RI. Undang-Undang Republik Indonesia Nomor 18 Tahun 2014 Tentang Kesehatan Jiwa. Jakarta: Kemenkes; 2014.

Koentjaraningrat. (2009). Pengantar IImu Antropologi. Edisi Revisi 2009. Jakarta: Rineka Cipta.

Paterson, D. L., Wright, H., dan Harris, P. N. (2018). Health Risks of Flood Disasters. Clinical Infectious Diseases, 67(9), 1450-1454.

Sameem, F., Aleem, S., dan Manzoor, S. Change in

\section{REFERENSI:}


Incidence of Dermatological Disorders after Major Floods in Kashmir Valley.

Sari, P. N., dan Nofriya, N. (2018). The Relationship of Flood Disaster With The Incidence Of Diarrhea, Water Quality And Community Resilience in Water Supply: A Case Study in The City of Bukittinggi. Jurnal Kesehatan Masyarakat Andalas, 12(2), 23-29.

Shives, L. R. (2011). Basic concepts of psychiatricmental health nursing (8th ed.). Philadelphia, PA: Lippincott, Williams, and Wilkins.

Shorter, M. D., dan Kosten, T. (2018). PTSD and Suicide After Natural Disasters. PSYCHIATRIC TIMES.
Stuart. G.W (2016). Prinsip dan Praktik Keperawatan Kesehatan Jiwa Stuart. Edisi Indonesia oleh Budi Anna Keliat dan Jesika Pasaribu. Elsevier: Singapore.

Thoits, P.A. (2015). Stress, coping, and social support processes: where are we? What next?. Nashville: Vanderbilt University.

Tim Pusat Krisis F.Psikologi UI, 2016, Dampak Psikologis Bencana pada Kelompok Rentan.

World Health Organization. Definisi Sehat WHO: WHO; 1947 [cited 201620 February]. Available from: www.who.int. 